\title{
Android-based Music Practice Material Completion Application
}

\author{
Rully Aprilia Zandra ${ }^{1}$ \\ Program Studi Pendidikan Seni Tari dan Musik, Fakultas Sastra, Universitas Negeri Malang
}

\begin{abstract}
Millennials and Z-generation were born in the modern era. Since their birth, they have been surrounded by sophisticated technology. This generation always gets information quickly and limitless. They are very familiar with the internet and applications on smartphones. The most common application is generally based on Android. Android must also be used in the world of education. Android applications can be realized as a tool to deliver learning or supervision of learning. Supervision of learning in this development is limited to material completion. This development was developed from a paper-based initial device. The device focuses on students' practical skills in music. For this purpose, peer tutoring forms in drill supervision are essential. This study used a Research and Development method modified from Borg and Gall in 10 steps. The steps used are research and information collecting, planning, develop a preliminary form of product, preliminary field testing, primary product revision, main field testing, operational product revision, operational field testing, final product revision, dissemination and implementation. The first score validation was $65,25 \%$ from the IT validator, $70,50 \%$ from the media validator, and $75,25 \%$ from the material validator. The mean values in the small group trials were 70.50 and 78.25 in the large group trials. The final score from validation was $92,50 \%$ form the IT validation, $77,25 \%$ from the media validator, and $84,75 \%$ from the material validator. Three applications must be developed as recommendations from the results of this research. These three applications are main teacher applications, admin applications, and student applications. Each application must be connected and updated in real-time.
\end{abstract}

Keywords: android application; learning supervision; music, educational technology; online supervision

\begin{abstract}
ABSTRAK
Aplikasi Penyelesaian Materi Praktik Musik Berbasis Android. Generasi Millenial dan Z lahir di era modern. Sejak lahir, mereka dikelilingi oleh teknologi canggih. Generasi ini selalu mendapatkan informasi dengan cepat dan tanpa batas. Mereka sangat akrab dengan internet dan aplikasi di smartphone. Aplikasi yang paling umum umumnya didasarkan pada Android. Android juga harus digunakan di dunia pendidikan. Aplikasi Android dapat direalisasikan sebagai alat untuk menyampaikan pembelajaran atau pengawasan pembelajaran. Supervisi pembelajaran dalam pengembangan ini terbatas pada penyelesaian materi. Perkembangan ini dikembangkan dari perangkat awal berbasis kertas. Perangkat ini berfokus pada keterampilan praktis siswa dalam musik. Untuk tujuan ini, formulir bimbingan teman sebaya dalam pengawasan bor sangat penting. Penelitian ini menggunakan metode Penelitian dan Pengembangan yang dimodifikasi dari Borg dan Gall dalam 10 langkah. Langkah-langkah yang digunakan adalah penelitian dan pengumpulan informasi, perencanaan, pengembangan bentuk produk awal, pengujian lapangan awal, revisi produk primer, pengujian lapangan utama, revisi produk operasional, pengujian lapangan operasional, revisi produk akhir, diseminasi dan implementasi. Validasi skor pertama adalah $65,25 \%$ dari validator IT, $70,50 \%$ dari validator media, dan $75,25 \%$ dari validator materi. Nilai ratarata dalam uji coba kelompok kecil adalah 70,50 dan 78,25 dalam uji coba kelompok besar. Skor akhir dari validasi adalah $92,50 \%$ dari validasi TI, 77,25\% dari validator media, dan 84,75\% dari validator materi. Tiga aplikasi harus dikembangkan sebagai rekomendasi dari hasil penelitian ini. Tiga aplikasi ini adalah aplikasi guru utama, aplikasi admin, dan aplikasi siswa. Setiap aplikasi harus terhubung dan diperbarui secara waktu nyata.
\end{abstract}

Kata kunci: aplikasi android; supervisi pembelajaran; musik; teknologi pendidikan; supervisi online

Correspondence: Program Studi Pendidikan Seni Tari dan Musik, Fakultas Sastra, Universitas Negeri Malang. Ph.: 0812330403060.E-mail: rullyzandra.fs@um.ac.id. 


\section{Introduction}

Millennials are people born in the period 1980 to 1995 . This generation is the one who goes through the millennium with everything that surrounds the millennium. This generation is also often referred to as the $\mathrm{Y}$ generation, and automatically it is also often produced as a Millennial generation because through the year 2000 with everything that surrounds it (Nindyati, 2017).

Generation $\mathrm{Z}$ is the generation born in the period 1995 to 2010 . This generation is generally born in a condition that has been surrounded by sophisticated technology. So this age group approaches close to technology in living their lives (Rohmiyati, 2018).

Both millennial generation and generation $\mathrm{Z}$ prefer to linger in front of the gadget screen (Nindyati, 2017; Rohmiyati, 2018). Good while surfing, playing games, or even shopping online. Watching movies in live streaming and even online courses is common in this generation. They always update about technology. Gadgets and internet connections are their daily partners (Yener, 2016), because this technology has more practical value and is economical to use.

Gadgets and internet connections are now common in millennials (Yener, 2016). Select the gadget to choose who uses Android for iOS (apple) users. This is because Android-based devices are easy and inexpensive to obtain from iOS-based device technology (Suwiprabayanti Putra, 2019).

Karyawati (Karwati, 2012) accepts that it is the same as iOS, android is an operating system software (software) that uses a computer code base that can be used openly or open source so that users can create new applications there. But iOS has fewer users and is only owned by certain segments. So from it android is a market that is easier to enter new applications.

The development of android technology also supports teachers who are already using smartphones. Related, the development of android technology can be a target to introduce teachers to applications that can help in the process of optimization, planning, implementation, and evaluation in the educational world. In addition to teachers, parents and students can actively participate in their supervision through Android technology. Specific assignments not only make student interaction transparent, but are better than the teacher but students can rearrange the meta support strategy throughout face-to-face progress (Susanti, 2013).

Recording technology and delivery of learning materials based on Android applications, is one way in implementing the latest learning updates and updates that make students know the material that has been achieved and what material has not been achieved in the time provided while it is running sementer (Suprayekti, 2005). Supervision of learning in educational technology designed on Android applications requires it to focus on the principles of responsibility and authority, periodic, coordination, openness, and sustainability (Mahedy, 2009). Submission of material that is transparent and with an open timeline can provide material rescue strategies for teachers and students to be able to complete the material on time and optimally (Susanti, 2013).

Android application-based education technology that is designed, is expected to be a new breakthrough integrated in designing, managing the entire learning process and learning. Hopefully, making learning work is more specific and based on learning research and communication by using a combination of learning resources from humans or non-humans to make learning more effective. Donald (Ely, 1983) added that through educational breakthroughs such as this, complex and integrated activities that use people, procedures, ideas, tools, and organizations can run solutically to analyze problems, arrange, connect, update, and find solutions to learning problems .

Mapping the problems of learning optimization can be mapped through paper based learning tools. Paper-based devices have been used by educators and have done well what was published was developed into something revolutionary (Ely, 1983; Karwati, 2012; Susanti, 2013) as in android on smartphones (Suwiprabayanti Putra, 2019)

Learning in the classroom is expected to run optimally with the application of the android 
application. Teachers are helped by the android application in maximizing the ability of students in music learning practice going forward.

Education is a means in the learning process or learning process. Mulyasa (Mulyasa, 2013) said that national education develops capabilities and makes character and civilization that is dignified and educates the nation. Education is a vehicle to provide knowledge to students.

The description proves that technology plays an important role in the world of education in accordance with the development of the current era which is increasingly advanced also proves that not only the negative impacts caused, but also the positive impacts that greatly affect the development of educational and social life (Mahedy, 2009). The role of media in learning is as important as education, which is very influential in students' acceptance of material. The development of instructional media is very necessary for the advancement of the world of education (Miftah, 2013).

Education is divided into two types, formal education and non-formal education. Formal education in the form of learning through schools is often called the teaching and learning process (Gunadi \& Aswir, 2019). Non-formal education is an education that is carried out outside the school environment, namely education in the family environment. Formal education learning activities can be monitored or seen directly through the teacher and student activity attendance book which is usually called the school learning journal. Non-formal education learning activities cannot be monitored or seen, because outside school hours there is no real evidence whether there are learning activities. The level of activity of formal and nonformal education learning can affect student achievement.

Based on preliminary studies conducted by three classes at the Malang-Indonesia music school, students do not have accurate records that are relevant to what the piano practice teacher claims. A small number of students do not even have a record of achievement and only follow what the teacher instructs them to face-to-face. The asynchronous and lack of notes on the achievement of student practice material can reduce the accuracy of the parent and student strategies in their pursuit of completeness independently.

The achievement of practical material on piano teaching tends to vary even in the same meeting. A student in the basic piano class at the fourth meeting has been able to play 4 scales and etude beyer number 30, while the second student in the same class at the fourth meeting also can only play one natural scale. Even this second student was only able to finish etude beyer 19 at the meeting. Thus there will be differences in performance of piano practice materials between students and other students recorded in the tutor book and the student's own task book. This paper-based notes are accommodated paperless in the android application that researchers developed.

Each student with different achievements will have the burden of remaining load with different volumes, this difference affects the way to optimize the time remaining differently as well. It is expected that the students' daily strategy setting will be triggered from applications that researchers have developed on the tools most widely used by the community.

Karwati (Karwati, 2012) asserted that the most widely used operating system on tablets and smartphones currently available is Android. Android is a favorite of producers and users because it has complete, high-performance features, capable of realtime, open, and free updates (Yener, 2016). Utilization of the application on the android platform as a choice of escort platform for achievement of development is based on the fact that android is the most widely used operating system, accessed every day and capable of realtime updates. These facts are the best reason to build the application of piano material drilling achievement in an android application that can make the tutor immediately know the achievement of practice in one face-to-face learning. What is the application that is able to help students and parents access the recording of practical achievements of each meeting, and how students can find out the assignments that must be done during the next 6 days, and how to use the record of the achievement of drilling piano in the application so that it can be used by students, students' parents, and tutors. 


\section{Method}

In this study using Research and Development $(\mathrm{R} \& \mathrm{D})$ research. According to Borg and Gall (Borg, 1983) Research and Development research methods which will then be abbreviated to $R \& D$ are research methods used to produce certain products, and test the effectiveness of these products. These products are not always in the form of objects or books, stationery, and other learning tools. However, it can also be in the form of software.

Research and information collecting is a stage to explore problems, find potentials and solutions, and collect data. After knowing the problem to be solved, the next step is planning or research planning. In the planning stage, researchers provide products to three validators, namely IT validators, media validators, and material validators to do stage I validation.

After planning has been validated by the three validators, planning that has been adjusted to the validator input is produced so that it can operate properly. This initial product was included in the preliminary testing field in a small group consisting of 1 teacher, 2 admins and 4 students. The results of trials in small groups are used to play product revision. The product was tested again on the main group testing field with a greater number than the small group trial, namely 1 teacher, 2 admins and 28 students.

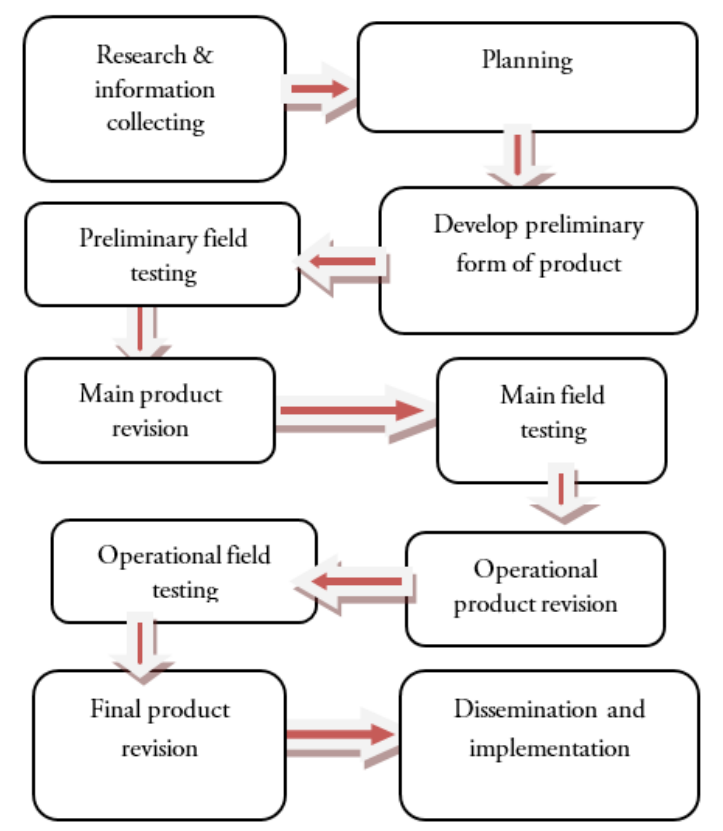

Figure 1. Steps from Borg and Gall. (1983:775)
Before the product is submitted to the validator for operational field testing as final validation, the product is first revised according to what was obtained in the main field testing of the large group. Through operational field testing, researchers find out the feasibility of the product. The final improvement of the product is developed into an application that is ready to be distributed to Android smartphone users.

This study uses two types of data, namely qualitative and quantitative. Qualitative data obtained from interviews with IT developers, multimedia experts, and material experts. They are research data regarding the response to the interface being tried. Interface that has been validated in the previous stage. Qualitative data obtained from questionnaires to teachers, students, and tutors. This questionnaire in the form of criticism, suggestions, and responses is used to determine the shortcomings of the media and to provide input to researchers that are useful in the product revision stage. Quantitative data is the percentage value of three validators and the percentage of student values in preliminary field testing and main field testing.

\section{Result and Discussion}

Development on educational media produces online apk-based learning media products that utilize android smartphones with learning media specifications having the logo icon image of the State University of Malang; layout sizes can be used on devices that have screens between 4 "(inches) to 6.4” (inches); media size of 97.6MB (Mega Byte).

Media products are not in Google Playstore, because this apk is not for sale. This Apk is directly sent via android social media and can be directly downloaded and installed for free. This Apk has three entry lines namely admission as a tutor, admin, and student.

\section{Media Operation Steps}

The first step in operating the media is to download an apk file that has been sent via a chat or email application. Furthermore, after the 
application has been downloaded and installed successfully, open the application and the dashboard will $\log$ in as shown in figure 2.

Figure 2 for the dashboard log in display, figure 3 for the tutor dashboard, figure 4 for the student dashboard. If students want to know the material and assignments on that day, click the material.

In figure 5, 6, 7 and 8 is a dashboard display for students. If you want to know the material to be learned face to face on figure 5 click the material then the material dashboard appears along with the assignment given by the tutor at the next meeting. In pictures 7 and 8 click the report on the dashboard and the report material appears for the next 6 weeks along with the next assignments.

In figure 9, 10, and 11 are the dashboard of the tutor. Figure 11 is a recap of the first meeting along with the meeting the following week for the tutor.
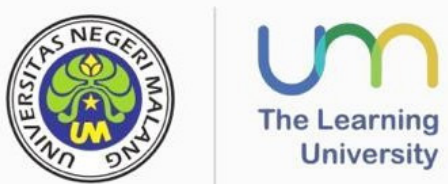

SUPERVISI PEMBELAJARAN

Email

Password a

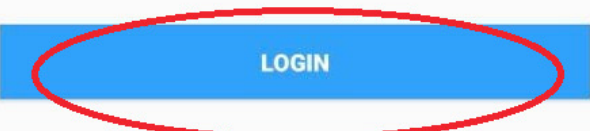

III

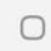

Figure 2. Tutor, admin, and student menu $\log$ in

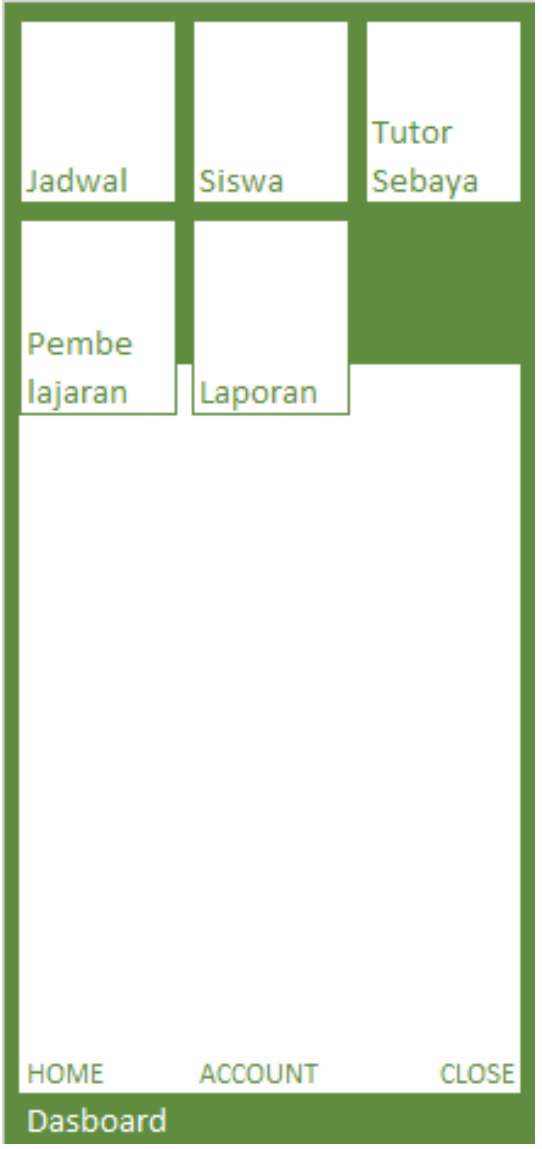

Figure 3. Tutor dashboard.

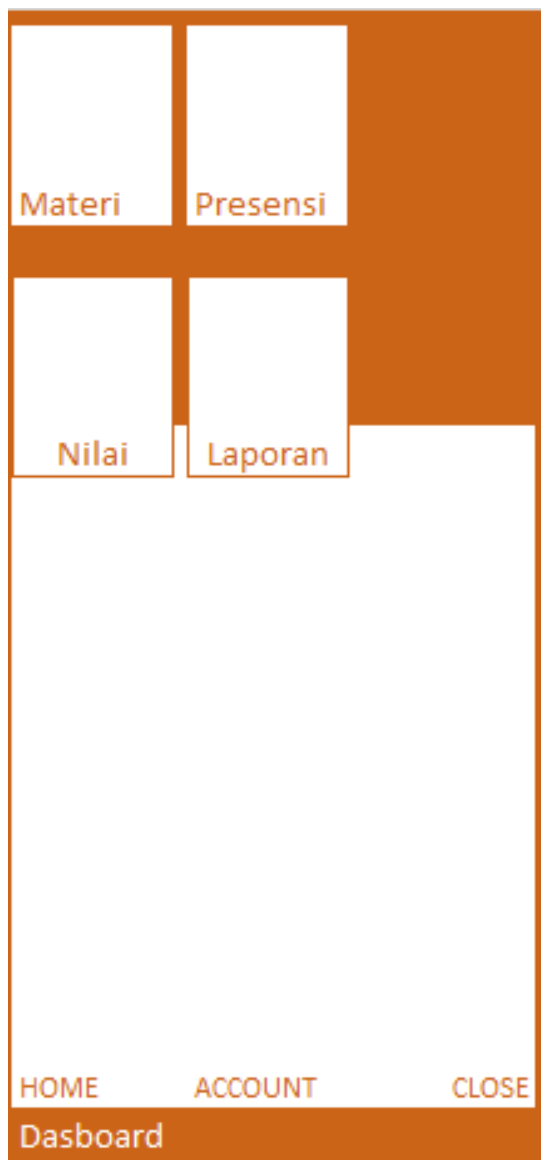

Figure 4. Student dashboard. 


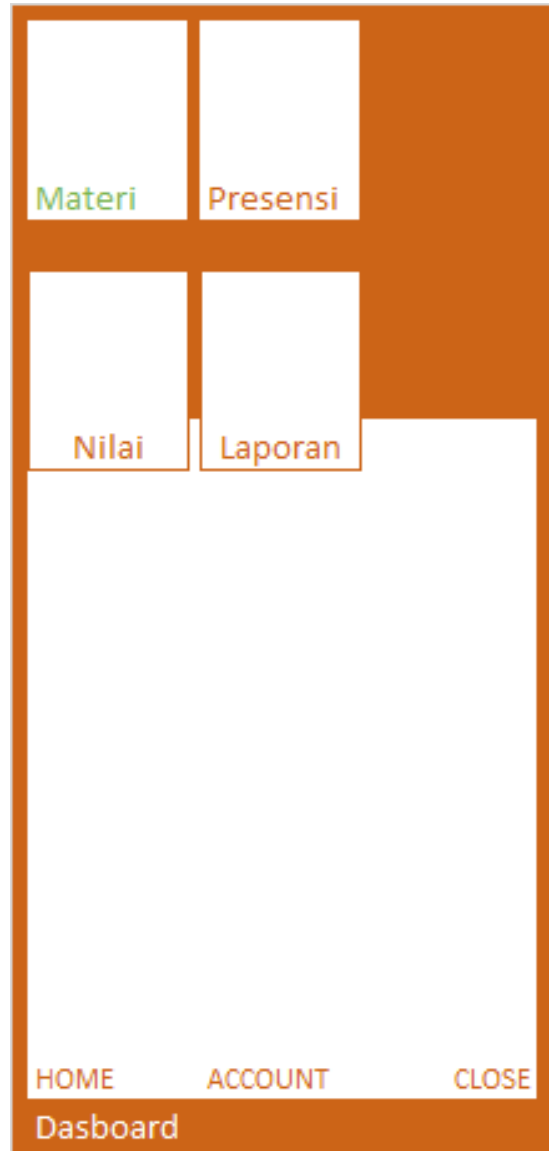

Figure 5. Click on Materi.

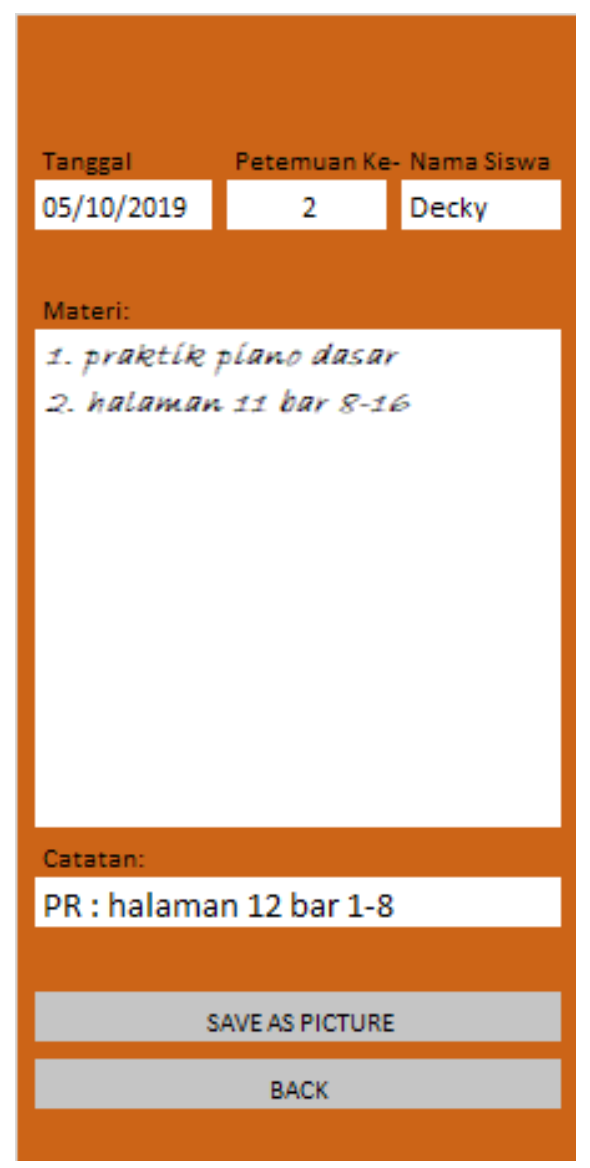

Figure 6. Material and assignments on that day.

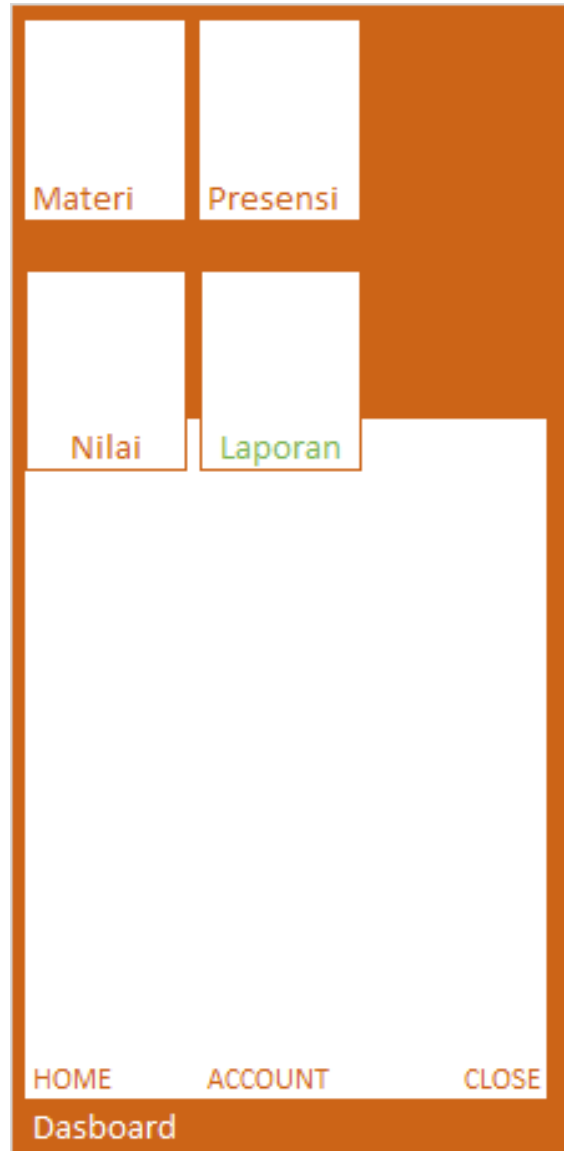

Figure 7. Click on Laporan.

$\begin{array}{ll}\text { Kelas } & 5 \\ \text { Jurusan } & \text { Piano Klasik } \\ \text { Hari } & \text { Minggu } \\ \text { Jam } & 13.00-13.30\end{array}$

$01109+2019$

\begin{tabular}{|c|c|}
\hline \multicolumn{2}{|l|}{ Halaman 11 bar $8-16$} \\
\hline & 08r09r2019 \\
\hline \multicolumn{2}{|l|}{ Halaman 12 bar $1-8$} \\
\hline & 1510912019 \\
\hline \multicolumn{2}{|l|}{ Halaman 12 bar $1-8$} \\
\hline & $22 \mathrm{r} 09 / 2019$ \\
\hline \multicolumn{2}{|l|}{ Halaman 12 bar $1-8$} \\
\hline & $29 / 09 / 2019$ \\
\hline \multicolumn{2}{|l|}{ Halaman 12 bar $1-8$} \\
\hline & $05+10+2019$ \\
\hline \multicolumn{2}{|l|}{ Halaman 12 bar $1-8$} \\
\hline & $12 / 10+2019$ \\
\hline \multicolumn{2}{|l|}{ Halaman 12 bar $8-16$} \\
\hline SAVE AS PICTURE & \\
\hline CANCEL & \\
\hline
\end{tabular}

Figure 8. Material and assignments for the next 6 weeks. 


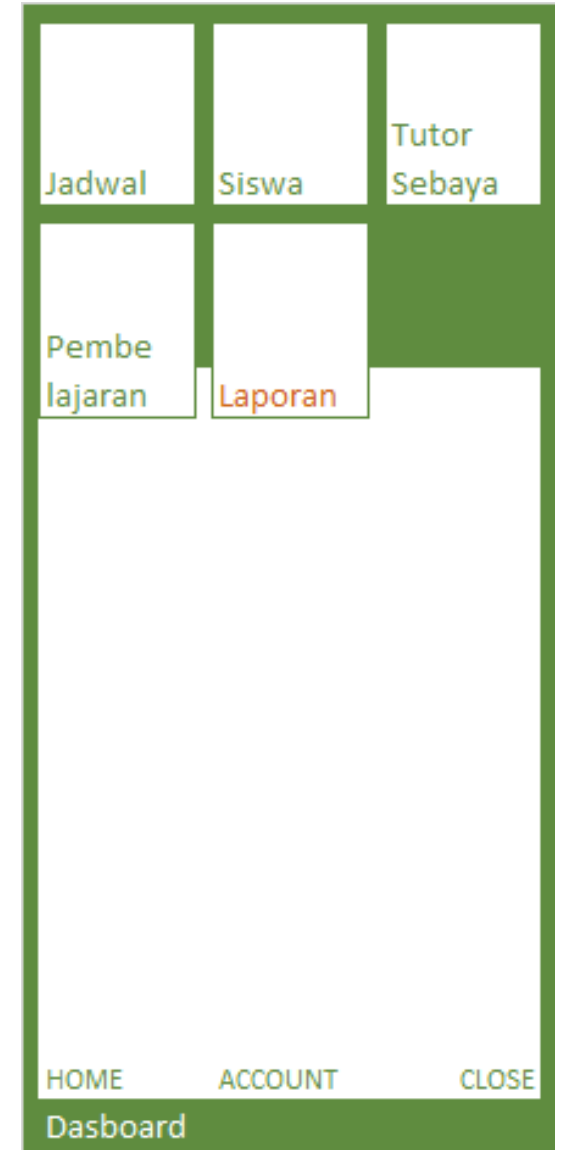

Figure 9. Click on Laporan.

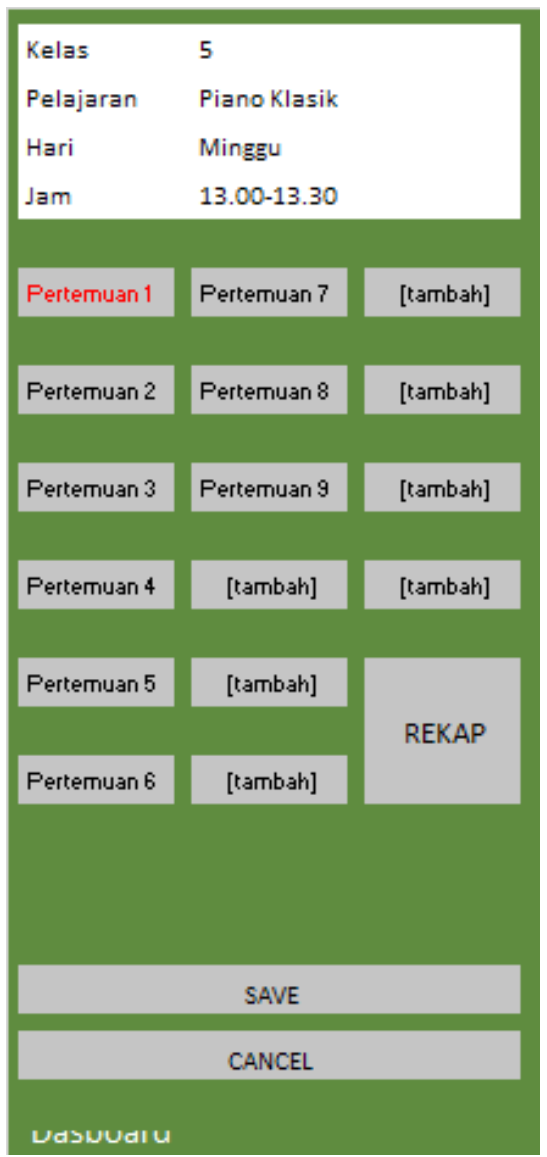

Figure 10. Click on Pertemuan 1.

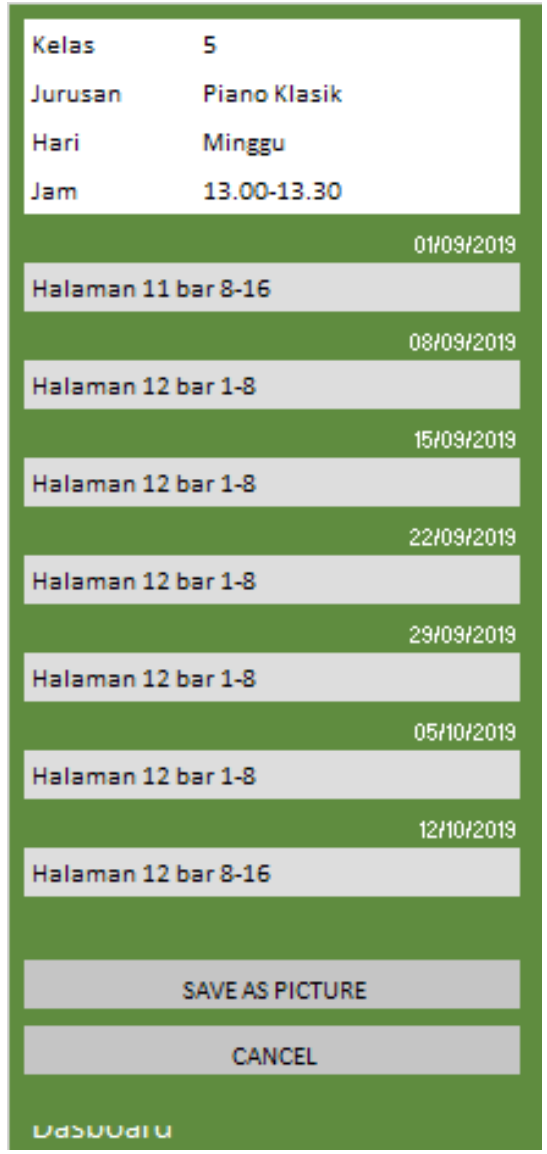

Figure 11. Recap of the first meeting along with the meeting of the following week for the tutor.

\section{Product Review}

Media achievement material for tutors and Android-based students can help tutors, and parents to monitor the activities of material achievements obtained by students wherever and whenever in accordance with the wishes of the user (user). This media can improve the achievements of the material obtained by students. Measurement of the validity of the media uses criteria adopted from Sugiyono (2015: 144). The validity criteria table can be seen in table 1 .

This media is validated to IT experts, media experts, material experts, and tested on students. The first validation was done on IT validator with the achievement of a percentage of $65.25 \%$, the

Table 1. Sugiyono's Validity Level Criteria. (2015:144)

\begin{tabular}{llll}
\hline \multicolumn{1}{c}{ Category } & \multicolumn{1}{c}{ Percentage } & \multicolumn{1}{c}{ Criteria } & Qualification \\
\hline Very good & $76 \%-100 \%$ & Valid & No revision \\
Pretty good & $51 \%-75 \%$ & Valid enough & Partial revision \\
Not good & $26 \%-50 \%$ & Not enough & Partial revision \\
Very bad & $0-25 \%$ & Invalid & Revision \\
\hline
\end{tabular}


media validator with the acquisition of a percentage of $70.50 \%$, while the material validator gave $75.25 \%$.

A note from the IT validator states that the application has a size that is too large. Thus, triggering the reluctance of prospective users to install on their smartphone. The large application size also requires a spacious RAM workspace, this has an impact on slow application performance or even lag on certain smartphone specifications. The dominance of the monopoly on RAM usage also has an impact on the deprivation of optimization of other applications that run together, it also triggers a slowing of multitasking on smartphones.

To solve this problem, the IT validator recommends splitting the application into three installers. The original one application for three functions, changed to three applications with each one function only. All one applications for three types of login, changed to three applications, each of which can only accept one type of $\log$ in. This division aims to divide up the basic size of the installer and divide the workload of applications on three different smartphones.

After getting suggestions from the validator, one application was changed to three applications, namely applications for students, applications for tutors, and applications for admins. Revamping the application is tested on a small group with a target of one tutor, two admins and students. The results show that $72.50 \%$ of the target can use the application properly. A note from a small trial states that tutors cannot input assignments directly, they must first pass the admin, this is considered as a barrier to the smooth delivery of tutor assignments to their students.

Settlement of small group trials then tested on large groups. Large group trials were tested on 1 teacher, 2 admins, and 28 students who were divided into two groups. The results of a large group trial showed $80.25 \%$. This percentage increased from a small trial which had a percentage of only $72.50 \%$. An increase in the results of small group trials to large groups showed results of $7.75 \%$.

Notes from large group trials reveal that the basic color selection for students must be empowering. Empowering color is a bright, warm, and encouraging color. The media validator recommends using the orange base color as a background. While the monochrome color as a button, text, and form completeness.

The media validator also recommends choosing shades that are comfortable and seen for a relatively long period of time. Media validators choose green for two reasons.

Material validation suggests there is a need to pay attention to students who are superior in practice and weak in practice. Students who are weak in good practice are facilitated by applications to be formed in groups and accompanied by tutors who are experts in the piano field. So the tutor can monitor how students progress for 1 week towards the next meeting.

The color choice for tutors is green, peer teaching is blue, while for students the color is orange. The admin and tutor applications are added with an input button for assignments at the next meeting so students and parents can know the assignments given by the tutor.

The input from IT validators in stage II validation is real time application development. So the application can be accessed by tutors, students, and admins in real-time or at the same time. Tutors can access the application at the same time as students open the application of material achievements in the face-to-face. Students can know firsthand what material will be learned as well as assignments given by tutors for the next 1 week.

The improvement of IT validator, media validator, and material validator shows an increasing percentage of validation test I. IT validator gives a percentage of $92.50 \%$, media validator gives a percentage of $77.25 \%$, and the percentage acquisition of $84.75 \%$ of the validator Theory. The results of stage II validation show that this application is feasible to be produced until the final stage.

The results of the validation as well as the results of trials on the two target groups indicate that the application is feasible to distribute. The target of this application is for students and tutors to make it easier to track the material that has been achieved in each face-to-face session. This application has also been able to help students, 
tutors and parents present students' data, which can arrange strategies used to achieve optimal material on the next face-to-face.

\section{Conclusion}

The production of capps applications must be developed in three types of applications. The application is divided into three types, namely tutor, student and admin applications. This application was developed so parents can be aware of it real time and tutors can give assignments directly in the application. So, tutors and parents can find out the development of material from students.

\section{References}

Ely, D. P. (1983). The definition of educational technology: An emerging stability. Educational Considerations, 10(2), 1-4. https://doi. org/10.4148/0146-9282.1793

Gunadi, R. A. A., \& Aswir, A. (2019). Feasibility Study Pengembangan Sumber Belajar Formal dan Non Formal. Prosiding Seminar Nasional Pendidikan KALUNI, 2, 739-748. https://doi. org/10.30998/prokaluni.v2i0.162

Karwati, U.-. (2012). Aplikasi Model Pembelajaran Sinektik (Synectic Model). Panggung, 22(2), 147-159. https://doi.org/10.26742/ panggung.v22i2.57

Mahedy, K. S. (2009). Peranan Teknologi Informasi Dalam Meningkatkan Kualitas Pendidikan.
Jurnal Pendidikan Teknologi Dan Kejuruan, 6(2), 55-70. https://doi.org/10.23887/jptkundiksha.v6i2.169

Miftah, M. (2013). Fungsi, Dan Peran Media Pembelajaran Sebagai Upaya Peningkatan Kemampuan Belajar Siswa. Jurnal Kwangsan, 1(2), 95. https://doi.org/10.31800/ jurnalkwangsan.v1i2.7

Mulyasa, E. (2013). Pengembangan dan Implementasi Kurikulum 2013.

Nindyati, A. D. (2017). Pemaknaan Loyalitas Karyawan Pada Generasi X dan Generasi Y. Journal Unpad, 1(3), 1-9. https://doi. org/10.24198/jpsp.v1i3.15230

Rohmiyati, Y. (2018). Model Perilaku Pencarian Informasi Generasi Milenial. Anuva, 2(4), 387. https://doi.org/10.14710/anuva.2.4.387-392

Suprayekti. (2005). Aplikasi Teknologi Pendidikan Bagi Guru dan Dosen. Journal, 2005(Snati), $1-7$.

Susanti, R. (2013). Teknologi Pendidikan Dan Peranannya Dalam Transformasi Pendidikan. Jurnal Teknologi Pendidikan, 2(2), 15-23. https://doi.org/10.32832/tek.pend.v2i2.448

Suwiprabayanti Putra, I. A. G. (2019). Implementasi Resource Traffic Management System pada Sistem Operasi Android Dan iOS. Eksplora Informatika, 8(2), 85-94. https://doi.org/10.30864/eksplora.v8i2.164

Yener, M. (2016). Expert Android ${ }^{\oplus}$ Studio. In Android Application With Android Studio (pp. 45-79). 


\section{WRITING INSTRUCTIONS}

\section{Title}

[Title must succinctly describes the contents of the research article and attract the academic readers. The title consists of 8-12 words, not including definite article (the) and indefinite article ( $a$, an). Use the phrases, not sentence.].

\section{Author(s)}

[Author must fill out author's profile that consist of author First, Middle and Last Name (If author only uses one name, fill the first name and last name with the same name), Gender, Initial, Username, Password, Affliation (University/Institution), E-mail, Mailing Address (complete address of affiliation), Country and Bio Statement. Author(s) must follow the journal template which can be downloaded at http://journal.isi.ac.id/index.

php/resital

\section{ABSTRACT}

The abstract is a summary of the article. It is consist of aim/goal/problem of research, research methods, results and discussion, and conclusion. Implications or recommendation can be added in the abstract. The abstract must be written in 150-250 words. The abstract must not contain lengthy background information and have no reference to figure, table, equation, any bibliographical reference either coming within or other article. The language of abstract must be clear and concise. It is a stand-alone summary in one paragraph.

Keywords: it contains 3-5 important words that are taken from the title and the content of the paper

\section{Introduction}

The introduction show what is already known from the previous studies, defines the importance of the study, literature review, and state the research question. In order to understand what is already known from the previous study, the introduction must consist of discussing the relevant journal article (with citation) and summarizing the current understanding of the problem encounter. The methods explain clearly how the author carried out the research. The method must describe the research design clearly, the replicable research procedures, describe how to summarize and analyze the data.

\section{Result and Discussion}

The result section shows objectively the presentation of the research key results without any interpretation using text, tables and figures. The result section begins with text, presenting the key finding, and referring to the tables and figures. The table must not print screen, specific numerical values, compare and contrast values, and minimum of 2 row and column. The figures must clear (provide original file as supplementary file in article submission), highlight trends, pattern, and relationship. The result section must present how the author ensure the data validity and reliability

The discussion section shows how the author interprets the results in light of what are already known, and to explain the new understanding of the problem after taking your results into consideration. The discussion must connect with the Introduction so it tells how your study contributes to the body of knowledge and society.

Tabel 1. Student Distribution Frequency

\begin{tabular}{|c|c|c|c|c|}
\hline No. & Interval & Frequency & $\%$ & Category \\
\hline 1. & $85-100$ & 59 & 28.36 & Very Good \\
\hline 2. & $75-84$ & 93 & 44.71 & Good \\
\hline 3. & $65-74$ & 37 & 17.78 & Average \\
\hline 4. & $55-65$ & 19 & 09.15 & $\mathrm{Bad}$ \\
\hline & Jumlah & 208 & 100.00 & \\
\hline
\end{tabular}

Figure 1. Speed Changing Tool
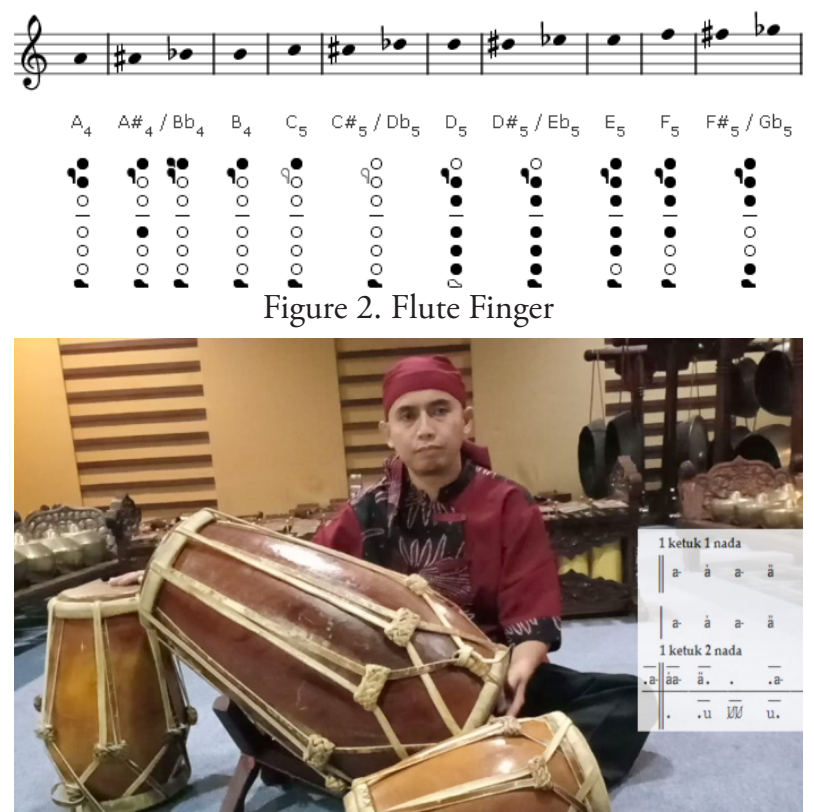

Figure 3. Kendang Practice (Source: Asep, 2017) 


\section{Conclusion}

The conclusions section show the answer or clarification of the research questions and opportunities for future research.

\section{References}

The reference must consist of $80 \%$ from relevant and recent primary sources (such as article of journal or conference from last 5 years). The reference must be written in APA style and using reference manager software Mendeley.

\section{Journal Article}

B Budi, D. S. U., Soedarsono, R. M., Haryono, T., \& Narawati, T. (2014). Angklung Dogdog Lojor pada Upacara Seren Taun. Resital: Jurnal Seni Pertunjukan, 15(2), 139-151. Retrieved from http://www.journal.isi.ac.id/index.php/ resital/article/view/848.

\section{Book}

Suharto, Edi. (2014). Membangun Masyarakat Memberdayakan Rakyat: Kajian Strategis Pembangunan Kesejahteraan Sosial \& Pekerjaan
Sosial. Bandung: Refika Aditama.

\section{Thesis, Dissertation, and Research Reports}

Prasetya, H.B. (2012). Melesed dan Nggandhul dalam Karawitan Pedalangan Gaya Yogyakarta. Universitas Gadjah Mada Yogyakarta.

\section{Conference Proceedings}

Muthmainnah, L. (2017). Perancangan Kampanye Penanggulangan Dampak Lagu Dewasa Terhadap Anak-Anak. e-Proceeding of Art and Design, 4(2), 138-146.

\section{Audio/Video}

Sugito, Hadi. (2005). Lakon Semar Gugat. (Cassete). Semarang: Fajar Record.

\section{Informant}

Handiman (79 years old). Angklung Craftman who is the student of Daeng Sietigna. Jln. Surapati No. 95 Bandung 40123.

\section{Article Submission}

Article should be uploaded through Open Journal System of http://journal.isi.ac.idlindex.php/resital 